\title{
Safety and Operational Performance of Roundabouts
}

\author{
Li-Sian Tey, M. S. Salim, Shahreena Melati Rhasbudin Shah, Prakash Ranjitkar
}

\begin{abstract}
When there are two or more roads meet, there is higher tendency of conflicts among vehicles. Roundabout is not a new concept to manage conflict points at at-grade intersection. However, improper motorist behaviours especially during peak hour affect safety and operational performance of a roundabout. This paper compares the safety and operational performance evaluation of a conventional non-signalized roundabout and a conventional signalised roundabout and explores the potential of turbo roundabout to replace the conventional ones. Three characteristics used to evaluate safety performance of the roundabouts include entry lane selection, use of entry and exit indicators, and weaving activities. These behaviours create the possibility of conflict, hence, risk of fatalities. On the other hand, delay and total time travel are used as indicators of operational performance of the roundabouts. We used SIDRA INTERSECTION Software to determine the theoretical delays and Level of Services. High delay, a time factor, affects motorists' emotion, might have contributed to the safety performance. Similarly, motorists' non-compliance behaviours affected the operational performance.
\end{abstract}

Index Terms: Conventional roundabout, turbo roundabout, operational performance, safety performance, driver behavior.

\section{INTRODUCTION}

A roundabout is an at-grade intersection, which connects more than one approach at a time. Roundabout is not a new concept to the highway systems. Hellier in 1913 to 1914 proposed circular traffic systems that meet several main roads and the circular system would prevent overload [1]. As the modernisation started, Great Britain came up with "yield at entry" rule. Roundabout counts react with higher performance to several aspects such as traffic flows and regulations, aesthetical value, and improve safety compared to other types of at-grade intersections.

Continued successes of modern roundabout depend on improvement of knowledge on the factor that contributed to the efficiency of the roundabout [2]. Several factors affect the safety and operational performance of the roundabouts such as, the geometry, driver behaviour, light and heavy vehicle characteristic, behaviour and requirements of other road users, traffic flow characteristic and operation of traffic

Revised Manuscript Received on September 22, 2019.

Li-Sian Tey, Faculty of Civil Engineering, Universiti Teknologi MARA, Cawangan Pulau Pinang, Permatang Pauh, Malaysia.

M. S. Salim. Faculty of Civil Engineering, Universiti Teknologi MARA, Cawangan Pulau Pinang, Permatang Pauh, Malaysia.

Shahreena Melati Rhasbudin Shah, Faculty of Civil Engineering, Universiti Teknologi MARA, Cawangan Pulau Pinang, Permatang Pauh, Malaysia.

Prakash Ranjitkar, Transportation Reseasrch Centre, Department of Civil and Environmental Engineering, Faculty of Engineering, University of Auckland, Auckland, New Zealand. control [3]-[6]. The conventional multilane roundabout has become an effective solution to cope with relatively high traffic demands. However, the additional entry and circulatory lanes increase the safety problems as well. These problems mostly are the effect of improper driving behaviour of drivers in the roundabout including entry and in circulatory. Previous studies on two-lane roundabouts encountered improper behaviour as being common practice, resulting in conflicts and increased likelihood of crashed [7]. Failure to give signals/indicators during merging and diverging in the roundabout's circulatory might be one of the causes of accident. On top of that, inexperienced driver might have problems to decide which lane should be their entry resulting in need of weaving which then cause other vehicle to slow down and increased conflict points. Previous research also found that roundabouts with higher approach speeds and higher traffic volumes experienced more runoff road crashes [8].

Nevertheless, roundabouts are indeed better at controlling traffic depending on the capacity, size and type. Different criteria give different result in term of efficiencies. A turbo roundabout is the one in which drivers are channelised from the entry into the paths designated for maneuvers to the intended exit by mountable lane divider installed on the
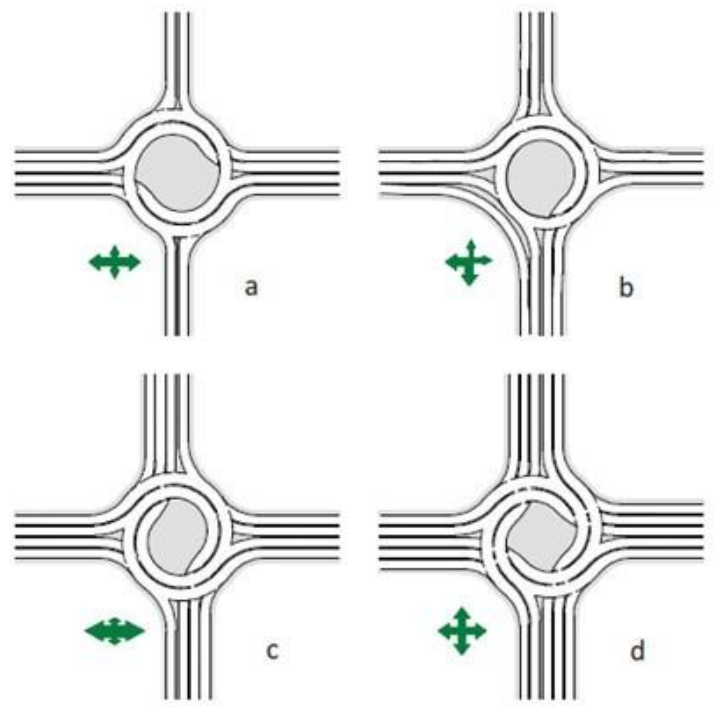

Fig. 1. Typical Turbo Roundabout Designs (Silva, Vasconcelos, \& Santos, 2014)

circulatory roadway, as shown in the diagram in Fig. 1. The physical seperation of traffic flows required the driver to decide the selection of entry lanes before entering the roundabout, hence, significantly reduce the number of conflict points in the roundabouts by eliminating the 
weaving movement. The turbo roundabout was introduced in Netherlands to overcome some of the issues faced by conventional roundabouts, which showed an $80 \%$ reduction risk of casualty accidents [9]. Elisha et al. [10] confirmed that turbo roundabout performs better, with a minimum of $92.5 \%$ of the drivers making correct lanes choices compared with $81.4 \%$ for two-lane roundabout. The finding can be attributed to having lanes that are physically separated by raised dividers, which help channel vehicles into the correct lane at the entry and exits. Unfortunately, the application of turbo roundabout is not widely used as this new type of roundabout is still in discussion in term of safety and improvement of capacity.

Malaysia is among the top three countries in the world with the deadliest roads. According to the data, Malaysia registered a death rate of about 23 per 100,000 population. Based on this statistic against the estimated population of 30 million Malaysians, about 7,000 to 8,000 people in the country die on the roads every year. It was reported that a total of $80.6 \%$ of the road accidents are caused by human error. The main reason accidents happened was attributed to people driving recklessly or ignoring traffic rules, instead of road and vehicle conditions [11]. For a nation that is aspiring to become a developed country, Malaysia should look towards decreasing its traffic-related death rate. From the aspect of road facilities, conflict points should be reduced. Turbo roundabout, a proven roundabout design with high safety and operational performance records in Europe, is worth being investigated for its local implementation potential.

The primary goal of the current paper is to compare how the localised driver behaviour been affected by the roundabout designs, which directly influenced its safety and operational performance. The number of vehicles passing the roundabouts increased due to increment of population compared to when it was first proposed. Two case studies were investigated; namely, Roundabout Community Seberang Perai at Jalan Permatang Pauh, Penang, and Roundabout Seberang Jaya, Penang. The similarity of these roundabouts is both served for high traffic demand especially during peak hours and both are three-lane conventional roundabouts. The first roundabout is a non-signalized three-lane conventional roundabout with yield line control. The latter is signalised three-lane roundabout with stop line set back control with additional alternative path to go straight and making a left turn. In addition, comparison was made to explore turbo roundabout as an alternative design in term of the safety and operational performance.

\section{METHODOLOGY}

\section{A. Study Sites}

There were two case studies included for comparison. Similar traffic volume and geometric was observed for both roundabouts except that one is non-signalised three-lane roundabout with yield line control while the other is signalized with stop line set back control. The first study area was Roundabout Community Seberang Perai, Jalan
Permatang Pauh, situated near Bandar Perda in Seberang Perai, which is also known as Province Wellesley. It is located at $5^{\circ} 21^{\prime} 52.5^{\prime \prime} \mathrm{N}$ and $100^{\circ} 25^{\prime} 31.1^{\prime \prime} \mathrm{E}$. The roundabout connects four main roads among residential area, shopping complexes, factories, city centre, universities and Penang bridge, which make the traffic demand increased rapidly during peak hours. There is a flyover acts as the "knee" of the roundabout, connecting Jalan Baru with Jalan Bukit Tengah, which reduced the traffic volume in the roundabout. Jalan Permatang Batu was identified as the critical approach as this road was observed to have longest queue length during peak hour. This roundabout is a non-signalised conventional triple-lane roundabout with yield line control systems. The second study area is at Seberang Jaya, Penang. This signalised conventional triple-lane with stop line set back control roundabout is located at $5^{\circ} 23^{\prime} 58.2^{\prime \prime} \mathrm{N}$ and $100^{\circ} 24^{\prime} 23.3^{\prime \prime E}$. This roundabout is intersecting two major roads; namely, Butterworth-Kulim Expressway and North-South Expressway. It connects between many residential areas, shopping malls and city centres. It is one of the busiest roundabouts in mainland of Penang. This roundabout is signalised with stop line set-back control.

\section{B. Preliminary Observation}

Prior to conducting the study, we conducted preliminary observation to determine the peak hour and off-peak hour of the roundabouts and the critical approach. A multi bank tally counter was used to record the traffic compositions including Motorcycle, Passenger Car, Light Van, Medium Lorry, Heavy Lorry and Bus and then converted to Passenger Car Unit per Hour (pcu/hr). The volume and queue length of vehicles at critical lane with heaviest congestion was recorded. We conducted preliminary data collection on $10^{\text {th }}$ October 2017 (Tuesday) at Roundabout Community Seberang Perai and 11 ${ }^{\text {th }}$ October 2017 (Wednesday) at Roundabout Seberang Jaya. For both roundabouts, the peak hour was determined at 7-8 am for operational performance evaluation while off-peak hour was determined to be at 3-4 pm for safety performance evaluation.

\section{Determination of Safety Performance}

For the safety performance evaluation, the investigation was done by License-Plate Observation during off-peak hour. It ensures that the driver have maximum freedom to manoeuvre in the circulatory such as merge or diverge compared to during peak hour. The increment of weaving activities might increase the conflict point in the roundabouts, thus influence the safety performance. We selected minimum of 50 subjects (vehicles) randomly for this evaluation so there were no biases on age, gender, or even type of vehicles. By this, worst case scenario of safety performance of the roundabout could be investigated.

We observed the subjected vehicles from the center of the island. Driver behaviours in term of entry lane selection, signal indications and weaving activity were adopted as the safety performance parameter of the roundabouts since it is one of the major problems that lead to potential conflicts at the roundabout. When a subject 
vehicle arrived at the roundabout, we recorded the plate number, type of vehicle, and entry lane selection. When the vehicles moved inside the circulatory, we recorded the signaling behaviour and weaving activities. A manual form was developed for the data collection purpose. The behaviour of the motorists was compared to Roundabout Rules and Regulations by Malaysia Public Works Department [12], as shown in Fig. 2. Any non-compliance with the rules and regulations was marked as non-compliance behaviour. Lane selection is important because incorrect selection will cause unnecessary weave activities inside the circulatory. For example, using inside lane to exit on the left. Whereas, failure to activate signal indicator especially when changing lanes or exit, will cause unawareness to other drivers. Sudden turn of vehicles will cause panic to other vehicles and thus result in emergency brake and will lead to accidents. Meanwhile, car weaving means that the cars change lanes inside the roundabout which may cause disturbance to the traffic flows.

We conducted the data collection on $16^{\text {th }}$ October 2017 (Monday) for Roundabout Community Seberang Perai and on $18^{\text {th }}$ October 2017 (Wednesday) for Roundabout Seberang. The results of safety performance for both roundabouts were compared with each other as signalised and non-signalised roundabouts and then compared with turbo roundabout theoretically.

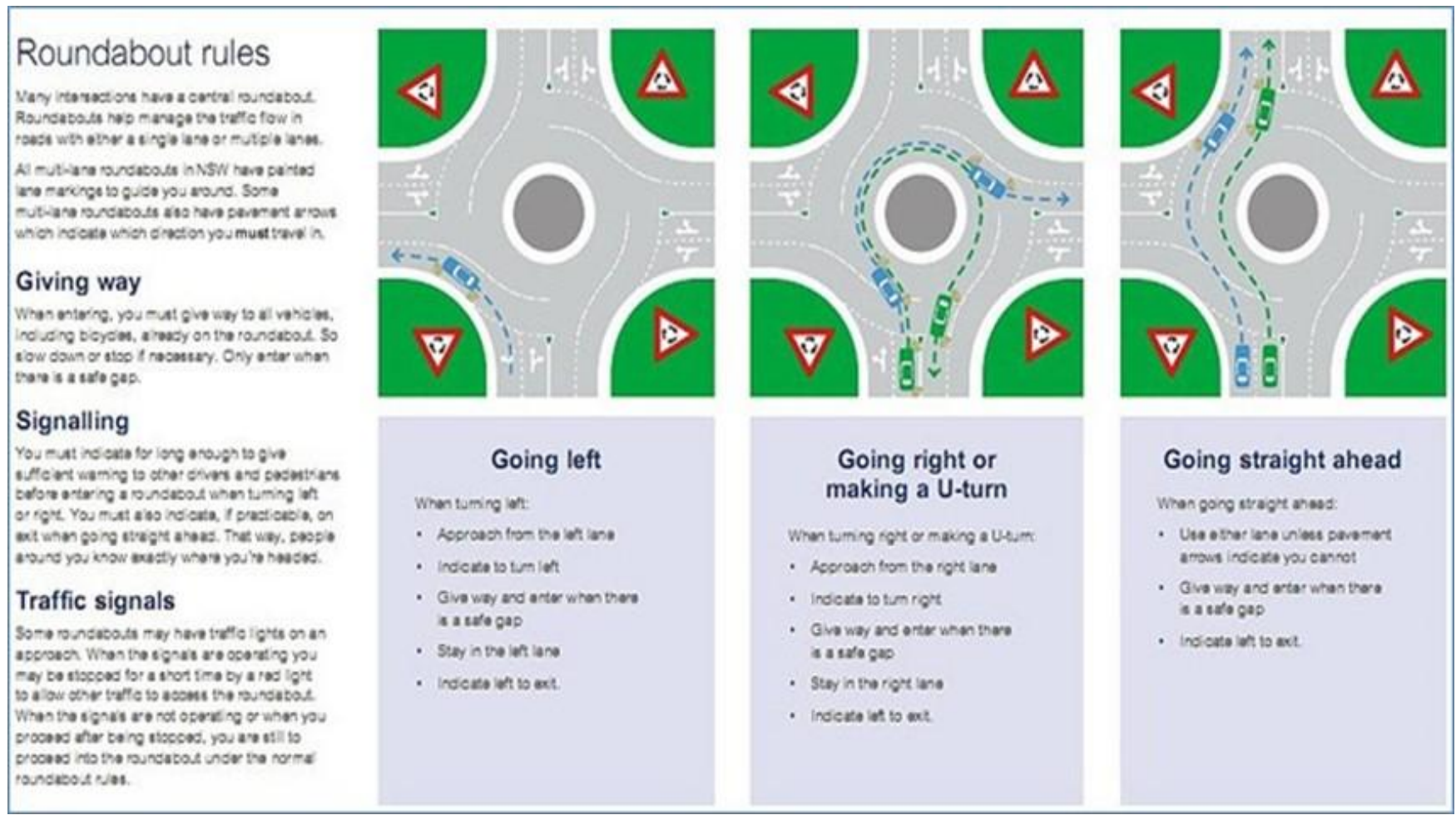

Fig. 2. Roundabout Rules

(Source: Jabatan Keselamatan Jalan Raya Malaysia, 2013)

\section{Determination of Operational Performance}

For operational performance evaluation, the field investigation was held during peak hour, determined as the maximum travel duration and delay. Two evaluators were involved in this study. 50 random vehicles were selected as the samples. Plate numbers and type of vehicles were recorded by the first evaluator that position at the back of the longest traffic queue to randomly pick a sample vehicle. The second evaluator was positioned at the entry of the circulatory with synchronized watch with the first evaluator. Communication with phone was done so that the same vehicles were recorded. The second evaluator recorded the time when the selected vehicles start to move inside the circulatory and recorded another time when the vehicles exit the circulatory. The travel time taken starting from when the vehicles arrived at the entry, inside circulatory and until exit was collected by using stop watch to determine the overall travel duration of the vehicle through the roundabouts. A form consisted of plate number, vehicle type, starting time, delays, and travel durations were generated. The results were then analysed in SIDRA INTERSECTION Software to obtain the theoretical delay and the Level of Services. We conducted the data collection of operational performance for Roundabout Community Seberang Perai on $20^{\text {th }}$ October 2017 (Friday) and at $19^{\text {th }}$ October 2017 (Thursday) for Roundabout Seberang Jaya.

\section{RESULTS AND DISCUSSIONS}

\section{A. Safety Performance Evaluation}

Fig. 3 and 4 show the percentage of non-compliance behaviours that were observed during the evaluation. High number of non-compliances was observed at Roundabout Community Seberang Perai on the entry signaling behaviour $(90 \%)$ while exit indication was $36 \%$. It shows that most drivers freely merge without giving signals to warn others. $20 \%$ non-compliances on unnecessary weaving manoeuvres were observed at 
the roundabout. Unnecessary weave is when the drivers diverge or converge without any necessary reasons in the circular of the roundabout. $24 \%$ of wrong entry selections were recorded. The entry selection was compared with the rules and regulations according to their exit leg shown in Fig. 2.

Compared to Roundabout Community Seberang Jaya, Roundabout Seberang Jaya

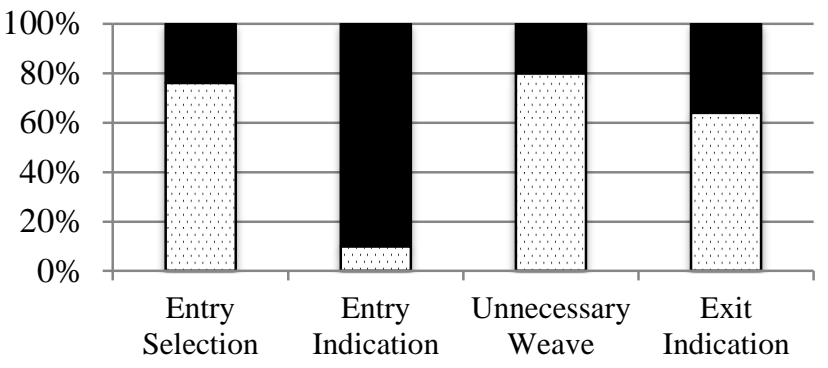

$\square$ Correct Behavior $\square$ Incorrect Behavior

Fig. 3. Driver Compliance Behaviour at Roundabout Community Seberang Perai

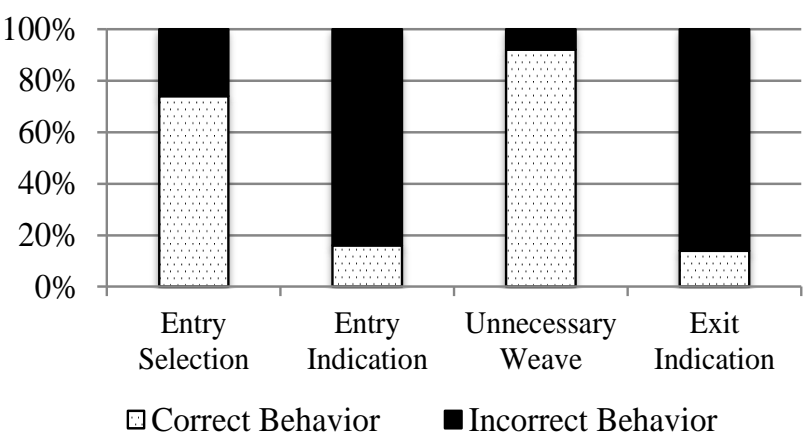

Fig. 4. Driver Compliance Behaviour at Roundabout Seberang Jaya

had higher non-compliance on the exit indication of $86 \%$. This is probably due to the traffic lights that control the traffic flows. The control device reduced the awareness of the drivers to give signals as they assume that no vehicle from other approaches will be intersecting. $26 \%$ of wrong entry selection was observed and only $8 \%$ on the unnecessary weaves.

\section{B. Operational Performance Evaluation}

Fig. 5 and 6 show the result for the delay and total travel time of the vehicles. The bars show the running time and delays of the vehicles at the circular of the roundabouts. The combination of both become the total travel time of the vehicles from the critical approaches through the circular of the studied roundabouts.

The operational performance at Roundabout Community Seberang Perai was determined in term of the average delay time, and average total duration. The average delay recorded at the critical lanes for the roundabouts was 5 minutes and 19 seconds. The average total travel duration is 5 minutes and 39 seconds. The delay is $94 \%$ of the total travel duration.

For operational performance at roundabout Seberang Jaya the average delay time recorded was 5 minutes 48 seconds.
The average total travel duration is 6 minutes 14 seconds which was higher than Roundabout Community Seberang Perai. The delay is $93 \%$ of the total travel duration.

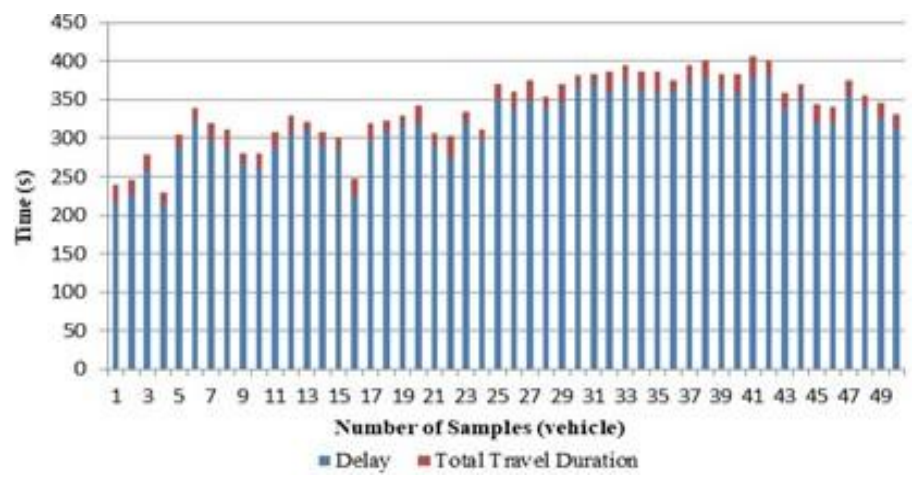

Fig. 5. Total Travel Time and Delay for roundabout Community Seberang Perai

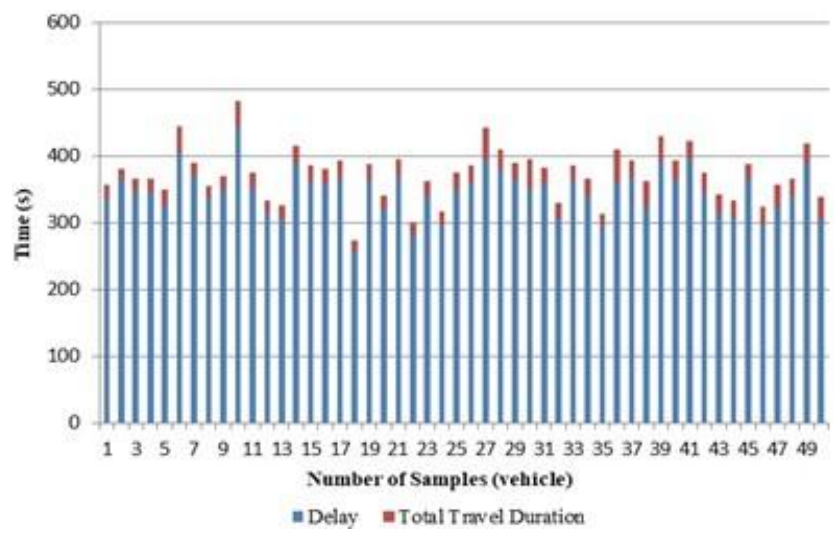

Fig. 6. Total Travel Time and Delay for roundabout Community Seberang Jaya

\section{SIDRA Analysis}

Geometric data such as island diameter, lane width and circulating lane width, traffic volume, path and movement data of the roundabouts were applied in SIDRA INTERSECTION Software. The average delays and Level of Services for the two roundabouts were generated, as tabulated in Tables I and II.

From the software analysis, the delay for the roundabout Community Seberang Perai and Seberang Jaya are 337.6 and 407.2 seconds respectively. The value difference between the SIDRA and field observation is between 5.8 to $17.24 \%$. The roundabout is at an unpleasant condition as the Level of Services (LOS) generated for the critical approaches is F with forced or breakdown flows. Frequent slowing is required as the vehicles are in the lockstep condition with the front vehicles. Obviously, the delay needs to be addressed. 
Table I. Sidra Intersection Analysis for Roundabout Community Seberang Perai

\begin{tabular}{llc}
\hline \multicolumn{1}{c}{ Approach } & $\begin{array}{l}\text { Average } \\
\text { Delay (s) }\end{array}$ & $\begin{array}{l}\text { Level of } \\
\text { Service }\end{array}$ \\
\hline $\begin{array}{c}\text { East: Jalan } \\
\text { Baru }\end{array}$ & & \\
Left & 334.3 & $\mathrm{~F}$ \\
Trough & 334.8 & $\mathrm{~F}$ \\
Right & 342.9 & $\mathrm{~F}$ \\
& 337.6 & $\mathrm{~F}$ \\
\hline
\end{tabular}

Table II. Sidra Intersection Analysis for Roundabout Community Seberang Jaya

\begin{tabular}{lcc}
\hline Approach & $\begin{array}{c}\text { Average } \\
\text { Delay (s) }\end{array}$ & $\begin{array}{l}\text { Level of } \\
\text { Service }\end{array}$ \\
\hline East: From Kulim & & \\
Left & 372.2 & $\mathrm{~F}$ \\
Trough & 372.2 & $\mathrm{~F}$ \\
Right & 462.0 & $\mathrm{~F}$ \\
& 407.2 & $\mathrm{~F}$ \\
\hline
\end{tabular}

\section{Discussion}

In term of safety performance evaluation, non-compliance of traffic rules at the two roundabouts is considered high. As shown in the Fig. 3 and 4, the percentage of the drivers failed to give direction indication during entry and exit to the roundabouts are high. These actions are seemed to be unimportant to many drivers, but the failure to provide direction indication could reduce the alertness of other drivers, thus could trigger panic reactions such as emergency braking. This action then may lead to collision and delay to other drivers. For Roundabout Community Seberang Perai the non-signalised roundabout, the outer lane was more frequently used by the motorists compared to the inner lane. This scenario might be due to the 'laziness' of the driver to change lane in the circulatory even when they are performing a right turn and U-turn. However, according to [12], the left lane is only for left turn and going straight ahead at the roundabouts while right lane must be used to perform right turn and U-turn. This is where the number of the incorrect selection of entry lane piled up. In addition, for both roundabouts, many drivers did not follow the circular path provided, instead, they maneuvered 'freely' in the roundabouts. For example, instead of driving within the lane marking, some of the drivers who wanted to go straight would move in 'straight line' ignoring the lane marking, thus created two conflict points. We also found many drivers changed lane in the circulatory. Due to high level of maneuver freedom, the alertness of the drivers is questionable. They might collide with other vehicles at their blind points through the rear or side mirrors with their unnecessary weaving. Surprisely, Roundabout Seberang Jaya has more incorrect behaviour compared to Roundabout Community Seberang Perai. The traffic lights, which supposed to be the merit, might have become the reason on the high record of incorrect behaviour. The drivers might feel more secure with the existence of traffic lights thus less exit indication was provided. Overall, the traffic lights might have helped in reducing unnecessary weaving at the circulatory but not much in promoting better driver behaviours in general.

In term of operational performance, both roundabouts had similar heavy traffic congestion scenario as LOF F during peak hour. From Fig. 5, a pattern of total travel duration and delay was observed from the data collected at Roundabout Community Seberang Perai. The pattern formed a curve which indicates the increment of the total travel duration and delay at $27^{\text {th }}$ until $47^{\text {th }}$ samples. Compared to Roundabout Community Seberang Perai, Roundabout Seberang Jaya does not have the same pattern because the traffic flow inside the roundabout is controlled by traffic lights. The controlled movement of traffic became the factor of the constant average delays and total time travel through Roundabout Seberang Jaya. At Roundabout Community Seberang Perai, the driver experience contributed a lot to the travel time and delay. Experienced drivers are less hesitant to merge into the circulatory while less experience will wait for the safest opportunity to enter the roundabout. When the traffic volume increase, gap of acceptance reduces, and the inexperienced driver will find more difficulties to merge into the circulatory. This explained the curve patterns in Fig. 5. For Roundabout Seberang Jaya, Fig. 6, a consistent pattern was observed. This is caused by the traffic lights which control the traffic flow. Experienced and inexperienced drivers will not find difficulties to enter the roundabout.

Driver behaviours play important roles in influencing safety and operational performance. An unexpected scenario was observed which worth mentioning was many motorcyclists did not enter the roundabouts to perform U-turn, instead they U-turn directly at the street divider of the entry lane. This risky behaviour caused the other drivers to slow down and give ways to them. It also caused the outer lane of the circulatory not been fully utilised as the motorists tried to avoid collision with the motorcyclists.

Unlike conventional roundabouts, turbo roundabout provides barriers to channel traffic from entry to exit, thus eliminates any possibility of weaving. It provides the best available solution to eliminate the issues of non-compliance behaviours raised in the current study. Fig. 7 shows the proposed typical turbo roundabout for Roundabout Community Seberang Perai. The lane ' 1 ' is the path that allows the vehicles that select the outer entry lane for left turn and going straight. The lane ' 2 ' directs the vehicles to go straight, right turn and U-turn. With this restriction, the vehicles would remain on their lanes and only converge or diverge when it is necessary, at the entry and exit, minimizing conflict points up to $50 \%$ [13]. With the reduction of conflict points, the safety of roundabouts is indeed improved as the risk of casualties for accidents was decreased by $80 \%$ when it was applied in Netherlands [9]. 


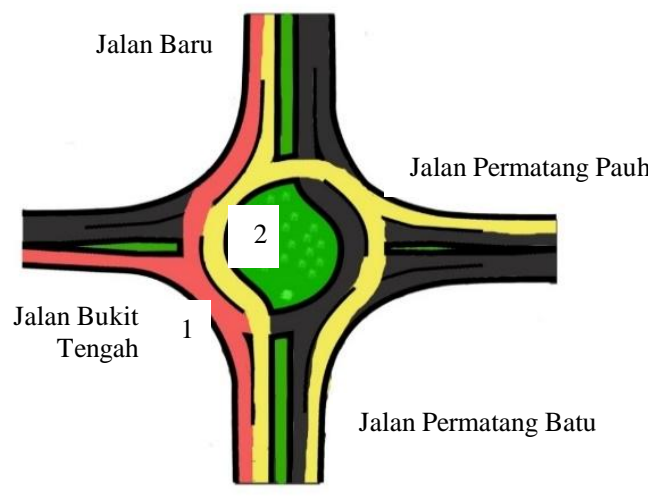

Fig. 7. Suggestion of Turbo Layout for Roundabout Community Seberang Perai

\section{CONCLUSION}

Obviously, improvement at both roundabouts, in term of the safety and operational performance is needed. Delay was high. Non-compliance rate of traffic rules was high. Overall, traffic lights at the roundabout did not play much role in improving the safety and operational performance measured in the current study. Nevertheless, since it is outside of the scope of the current study, it remains unknown whether it helps to bring down the accident rate. Implementation of traffic rules by police infringement fine may possibly help. However, the effect might be random.

Rather than changing the driver behaviours which may take much longer time, an immediate effect from alternative roundabout design, a turbo roundabout - proven to reduce $80 \%$ of risk of fatalities, was proposed. Other than safety aspect, turbo roundabout may also result in more capacity by forcing the drivers to use inner lanes. By forcing them to use inside lanes, the roundabouts are fully utilised.

\section{ACKNOWLEDGMENT}

The authors acknowledge the supports of this paper by the Perunding JPNS Sdn. Bhd. and the Universiti Teknologi MARA, Pulau Pinang Campus.

\section{REFERENCES}

1. Tollazi, T. (2015). Alternative types of roundabouts. An Infromational Guide, pp. 11 - 55

2. Akcelik, R. (2005). Capacity and performance analysis of roundabout metering signals. TRB National Roundabout Conference, (pp. 1 - 19). Vail, Colorado, USA.

3. Antonio Pratelli, Simona Casella, Alessandro Farina \& Marino Lupi (2018). Conventional and unconventional roundabouts: a review of geometric features and capacity models. International Journal of Transport Development and Integration, Vol. 2, Issue 3, 225 - 239.

4. Orazio Giuffre, Anna Grana, Maria Luisa Tumminello, \& Antonino Sferlazza (2018). Capacity-based calculation of passenger car equivalent using traffic simulation at double-lane roundabouts. Simulation Modelling Pratise and Theory, Vol. 81, 11 - 30.

5. Silva, A. B., Vasconcelos, L., \& Santos, S. (2014). Moving from conventional roundabouts to turbo-roundabouts. Procedia - Social and Behavorial Science, 137 - 146.

6. Beau Burdett, Andrea R. Bill, and David A. Noyce (2017). Evaluation of roundabout-related single-vehicle crashes. Transportation Research Record, No. 2637, 17-26.

7. Mauro, R., \& Branco, F. (2010). Comparative analysis of compact multilane roundabouts and turbo-roundabout. Journal of Transportation Engineering, 316 - 322 .

8. Elisha Jackson Wankogere, Valerian Kwigizile, Jun-Seok Oh, and Pavel Ikonomov (2017). Comparison of driver navigation at turbo roundabouts and modern two-lane roundabouts simulation study. Transportation Research Record, No. 2637, 89-98.

9. Tang Ruxyn (2017, June 21). Death rates on Malaysian roads is $3^{\text {rd }}$ highest globally, more than China and India. Retrieved from https://says.com/my/news/malaysia-s-roads-among-the-world-s-most-dang erous-and-deadliest (URL)

10. Jabatan Keselamatan Jalan Raya Malaysia (2013, July 31). Panduan di satu bulatan. Retrieved from http://www.jkjr.gov.my/v3/ms/direktori.html?catid=0\&id=1169:satu-pan duan-untuk-bulatan (URL)

11. Transoft Solutions Inc. (2017, June 14). Turbo roundabout - a better alternative. Retrieved from https://www.youtube.com/watch?v=MqFuAy5r4b8 (URL)

\section{Authors Profile}

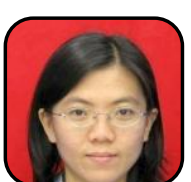

Dr. Li-Sain Tey is a Senior Lecturer in the Faculty of Civi Engineering at the Universiti Teknologi MARA, Cawangan Pulau Pinang. Her academic and research work focuses on transportation engineering, human factors, traffic safety, traffic modelling and simulation and pavement.

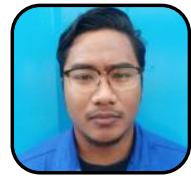

Mohd Syafiq bin Salim graduated from Universit Teknologi MARA Cawangan Pulau Pinang in 2019. He is currently working as a project engineer for a pipe jacking specialist company.

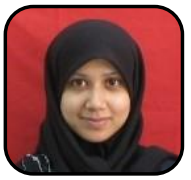

Shahreena Melati Rhasbudin Shah is a Senior Lecturer in the Faculty of Civil Engineering at the Universiti Teknologi MARA, Cawangan Pulau Pinang. Her research interests include pavement materials, traffic flow, driver behavior, and transportation engineering.

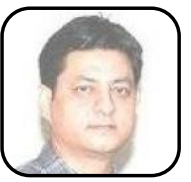

Dr Prakash Ranjitkar is a Senior Lecturer in Transportation Engineering in the Department of Civil and Environmental Engineering and a founding member of the Transportation Research Centre (TRC) at the University of Auckland, New Zealand. Prakash has over 19 years of academic, research and consulting work experience in a range of transport and other infrastructure engineering projects. He has strong research interests in modelling and simulation of traffic, intelligent transportation system, traffic operations and management, traffic safety, human factors and applications of advanced technologies in transportation. Prior to joining the University of Auckland in 2007, he worked for the University of Delaware in USA (2006-2007) and before that in Hokkaido University in Japan (2001-2006). Prakash is a member of IPENZ Transportation Group and Institute of Transportation Engineers (USA). He is an Editorial Board Member for the Open Transportation Journal and reviewer of Journal of Transportation Research Board, Journal of Eastern Asia Society for Transportation Studies, Journal of Intelligent Systems and IEEE Transactions of Intelligent Transportation Systems. 